\title{
Analysis of Technical Efficiency of Haricot Bean Production in Misrak Badawacho Woreda, Hadiya Zone, Ethiopia
}

\author{
Hassen Nurhussen ${ }^{1 *}$, Adam Bekele ${ }^{2}$ and Jema Haji ${ }^{3}$ \\ ${ }^{1}$ Wondogenet Agricultural Research Center, Agricultural Economics, Extension and Gender Research \\ Process, P.O. Box 198, Shashemene, Ethiopia \\ ${ }^{2}$ Melkasa Agricultural Research Center, Agricultural Economics, Extension and Gender Research Process, \\ Ethiopia
}

${ }^{3}$ Haramaya University, School of Agricultural Economics and Agribusiness Management, College of Agriculture and Environmental Sciences

\begin{tabular}{|c|c|}
\hline Abstract & Article Information \\
\hline $\begin{array}{l}\text { The study was conducted to assess the technical efficiency of smallholder farmers' haricot } \\
\text { bean production and its determinants, using Cobb-Douglas production function. For this } \\
\text { purpose, a cross sectional data was collected for } 2014 \text { production year from a random sample } \\
\text { of } 178 \text { haricot bean producing farmers living in the study area. The empirical result shows that } \\
\text { quantity of local seed, improved seed, Di-ammonium phosphate fertilizer, land allocated for } \\
\text { haricot bean, labor, and number of draught animals which were used in the production function } \\
\text { are the major factors that influence the changes. Results of technical efficiency of haricot bean } \\
\text { producers showed a mean value of } 78.25 \% \text { indicating that efficiency in haricot bean production } \\
\text { among farmers could be increased by } 21.75 \% \text { through better use of local seed, improved } \\
\text { seed, Di-ammonium phosphate fertilizer, land allocated for haricot bean, labor, and number of } \\
\text { draught animals in the short run. In addition, results of inefficiency analysis indicates that } \\
\text { draught animals ownership, age, extension contact, soil fertility status, and availability of } \\
\text { market and price condition of the output were negatively and significantly affect technical } \\
\text { inefficiency of haricot bean production implying that improvement in these variables improves } \\
\text { technical efficiency. However, total farm size, livestock size, farmer's involvement in off/non- } \\
\text { farm activities, and distance to the nearest main market were positively and significantly affect } \\
\text { technical inefficiency showing that these variables have negative influence on technical } \\
\text { efficiency. } \\
\text { Copyright@2015 STAR Journal, Wollega University. All Rights Reserved. }\end{array}$ & $\begin{array}{l}\text { Article History: } \\
\text { Received : 24-12-2014 } \\
\text { Revised : 08-03-2015 } \\
\text { Accepted : 18-13-2015 } \\
\text { Keywords: } \\
\text { Technical efficiency } \\
\text { Stochastic frontier analysis } \\
\text { Cobb-Douglas production } \\
\text { Haricot bean }\end{array}$ \\
\hline
\end{tabular}

\section{INTRODUCTION}

Agriculture is the mainstay of the Ethiopian economy. It accounts for about 40 percent of national gross domestic product (GDP), 90 percent of exports, and 85 percent of employment. The majority (90 percent) of the poor rely on agriculture for their livelihood, mainly on crop and livestock production (CSA, 2009).

Among crops, pulses have been cultivated and consumed in large quantities in Ethiopia for many years. They are important components of crop production in Ethiopia's smallholder's agriculture, providing an economic advantage to small farm holdings as an alternative source of protein, cash income, and food security. The major varieties of pulses grown in Ethiopia are: horse beans, chickpeas, haricot beans, lentils, dry peas and vetches. Haricot bean (Phaseolus vulgaris L.) is one of the most important grain legumes grown in the low lands of Ethiopia particularly in the rift valley for export and home consumption (Ethiopian Export promotion Agency, 2004).
A Number of improved varieties of food type (16 varieties) and export type (3 varieties) have been released by agricultural research centers in Ethiopia with on station productivity ranging from 1.6-4 tons/ha (EARO, 2004). In addition to this, the productivity of haricot bean in 2010/1 and $2011 / 2$ in Hadiya zone is 1.01 and 0.66 tons/ha (CSA, 2012). In Ethiopia, haricot beans accounted for $2.12 \%$ (more than 244 thousand hectares) of the grain crop area and $2.01 \%$ (3.63 million) quintals of the grain crop production in 2009 /10 production year (CSA, 2010) and it is one of the most important export crops in the country. Despite the fact that, Ethiopia has witnessed an upward trends in haricot bean production since 2000/1; it has mainly attributed to expansion in the area under cultivation. Though a number of high yielding varieties have been developed under the Ethiopian agricultural research system, the estimated average national productivity of haricot beans remains low which is 1 ton/ha (Katungi et al., 2010). 
Hassen Nurhussen et alo,

According to Colli et al. (1998) efficiency consists of two main components; technical and Allocative efficiency. And it is stated that technical efficiency occurs if a firm obtains maximum output from a set of inputs whereas allocative efficiency occurs when a firm chooses the optimal combination of inputs, given the level of prices and production technology. Though the productivity of haricot bean can be improved either by adoption of improved production technologies or improvement in efficiency or both, in a situation where there is low rate of adoption of improved technologies by farmers (Legese, 2004), improvement in efficiency becomes the best option in productivity enhancement in the short run. Therefore, the study was designed to estimate the level of technical efficiency of haricot bean producing farmers and to identify its determinants in the study area.

\section{MATERIALS AND METHODS}

The study was conducted in Southern Nation Nationalities and peoples Region, Misrak Badwacho Woreda of Hadiya Zone, Ethiopia. It is located at $37^{\circ} \mathrm{N}$ latitude and $37^{\circ} 46$ ' $36^{\prime \prime} \mathrm{E}$ longitude and at an altitude range of 1650-2050 m.a.s.I. The minimum and maximum annual rainfall of the area is 800 and $1200 \mathrm{~mm}$ respectively (MBWARDO, 2005). A two stage sampling technique was employed to select sample respondents. First, potential haricot bean producing kebeles were identified purposively and out of nineteen potential kebeles six kebeles were selected using simple random sampling. In the second stage, the lists of haricot bean producing farmers in the selected kebeles were identified in collaboration with Woreda agricultural and rural development office experts. The total number of respondents was determined by using a formula developed by Yamane (1967).

$$
\mathrm{n}=\frac{\mathrm{N}}{1+\mathrm{N}(\mathrm{e})^{2}}
$$

Where; $\mathrm{n}$ : is the required sample size; $\mathrm{N}$ : is the total number of farm households in the study area; $\mathrm{e}=$ is the level of precision which is assumed to be $7.5 \%$. Hence, the total sample size was 178 . Finally, the required sample respondnets in each kebele were determined based on proportions of haricot bean producer households of the respective kebele and Simple random sampling technique was followed to identify sample farm households. Both primary data and secondary data were used for the study. The primary data were collected for the 2013/4 production year through interviewing individual farm households by using structured questionnaires and well-trained enumerators. Finally, secondary information that supports interpretation of primary data was collected from Woreda agricultural office and different published and unpublished sources.

Literature suggests two methodological approaches for analyzing the sources of technical inefficiency based on stochastic production functions. The first approach is the two-stage estimation procedure in which first the stochastic production function is estimated and the efficiency scores are derived. In the second stage, the derived efficiency scores are regressed on explanatory variables using ordinary least squares or tobit regression. This approach has been criticized on grounds that the firm's knowledge of its level of technical inefficiency affects its input choices; hence inefficiency may be dependent on the explanatory variables. The second approach advocates a one stage simultaneous estimation
Sci. Technol. Arts Res. J., Jan-March 2015, 4(1): 234-241

approach as in Battese and Coelli (1995), in which the inefficiency effects are expressed as an explicit function of a vector of farm-specific variables (Chirwa, 2007).

Similarly, there are two approaches that can be used in measuring efficiency namely: the parametric and nonparametric models, which differ in two ways. First, they differ on assumptions of the distribution of the error term that represents inefficiency. Second, they differ in the way the functional form is imposed on the data. Parametric methods use econometric approaches to impose functional and distributional forms on the error term whereas the non-parametric methods do not (Hyuha et al., 2007).

The Stochastic Frontier Analysis (SFA) is an analytical approach that utilizes econometric (parametric) techniques whose models of production recognize technical inefficiency and the fact that random shocks beyond producers' control may affect the product (Constantin et al., 2009). Therefore, considering the limitations and practical relevance of the above methods, a one stage simultaneous estimation approach was used for estimation of technical inefficiency determinants whereas, stochastic frontier analysis was used for technical efficiency estimation. The basic parameter of the production function that incorporates inefficiency factors was estimated by Maximum Likelihood Estimation (MLE) technique through STATA and FRONTIER4.1 software. In estimating the frontier, a production frontier model can be derived which is developed by Battese and Coelli (1995) as:

$$
\mathrm{y}_{\mathrm{i}}=\mathrm{f}\left(\mathrm{x}_{\mathrm{i}} ; \beta\right) \exp ^{\varepsilon_{i}} ; \varepsilon_{\mathrm{i}}=\mathrm{v}_{\mathrm{i}}-\mathrm{u}_{\mathrm{i}} ; \text { where } \mathrm{u}_{\mathrm{i}} \geq 0
$$

Where: $y_{i}$ is output of farm $i, i=1,2 \ldots N$

$\mathrm{f}(\ldots)$; is the production technology

$\mathrm{x}_{\mathrm{i}}$; is vector of $\mathrm{N}$ inputs,

$\beta$; is vector of unknown parameters to be estimated, $\varepsilon_{i}$; is the error term with two components of $v_{i}$ and $u_{i}$ $v_{i}$ is non-negative error term (factors out of control of the farmer's decision) and is assumed to be independently and identically distributed $N\left(0, \sigma_{v}{ }^{2}\right)$.

$\mathrm{u}_{\mathrm{i}}$ is the technical inefficiency component (due to the decision or action of the farmer) Hence, the technical inefficiency term is expressed as:

$$
u_{i}=\sum \delta_{\mathrm{i}} \mathrm{z}_{\mathrm{i}}+\delta_{0} ; \mathrm{u}_{\mathrm{i}} \geq 0
$$

Where: $z_{i}$ factors affecting the technical efficiency of the farm and $\delta_{i}$ is coefficient of the parameter to be estimated.

By using the parameterization of Battese and Corra (1977) the above models can be estimated in terms of the variance parameters as:

$$
\sigma^{2}=\sigma_{\mathrm{v}}^{2}+{\sigma_{\mathrm{u}}}^{2} \text { and } \gamma=\frac{\sigma_{\mathrm{u}}^{2}}{\sigma_{\mathrm{v}}{ }^{2}+\sigma_{\mathrm{u}}{ }^{2}}
$$

The parameter omeasures the discrepancy between frontier and observed levels of output and is interpreted as the total variation in output from the frontier attributable to technical inefficiency. It has a value between zero and one. The value of zero indicates that the non-negative random variable, $u_{i}$ is absent from the model while the value of one shows the absence of statistical "noise" from the model and hence low level of farm's production compared to the" best "practice (the maximum output) of the other farm that is totally a result of farm specific inefficiency. 


\section{Model Specification}

As Colli et al. (1998) describes different algebraic form of a function give rise to different models. Some common functional forms are linear, Cobb-Douglas, quadratic, normalized quadratic, translog, generalized Leontief, and constant elasticity of substitution. The Cobb-Douglas functional form of production functions which was proposed by Wicksell (1851 - 1926) and tested against statistical evidence by Charles Cobb and Paul Douglas in 1928 (Tan, 2008) is widely used to represent the relationship of an output to inputs. Therefore in this study, a Cobb-Douglas production functional form of:

$$
Y_{i}=\beta_{0} \prod_{i=1}^{6} X_{i}^{\beta_{i}} * \exp ^{\varepsilon_{i}} ; \text { where } Y_{i}, X_{i}, \beta_{i} \text { and } \varepsilon_{i} \text { are as defined in equation2 (5) }
$$

was employed and the simplified logarithmic functional form was stated as:

$$
\ln Y_{i}=\ln \beta_{0}+\beta_{i} \sum_{i=1}^{6} \ln X_{i}+v_{i}+u_{i}
$$

Where: In: Represents natural logarithm

$Y_{i}$ : Haricot bean output (in ton) for the $i^{\text {th }}$ farm household $\mathrm{X}_{\mathrm{i}}$ : Vector of explanatory variables of the $i^{\text {th }}$ farm household

$\beta_{0}$ : Constant and $\beta_{1} \beta_{6}$ : are parameters to be estimated and represents elasticity of production. $v_{i}$ and $u_{i}$ are as defined above.

The inefficiency model is:

$$
u_{i}=\delta_{0}+\sum_{i=1}^{16} \delta_{i} z_{i}
$$

Where: $u_{i}$; is inefficiency of the $i^{\text {th }}$ farm household. $Z_{i}$; Vector of farm/farmer specific, socioeconomic and institutional variables of the $i^{\text {th }}$ farm household. $\delta_{0}$; Constant and $\delta_{1}-\delta_{16}$; are parameters to be estimated

Before the final analysis, the data was checked for outliers and multicolinearity problem. For test of multicollinearity problem, Variance Inflation Factor (VIF) was used. According to Maddala (1992), VIF can be defined as:

$$
\operatorname{VIF}\left(\mathrm{X}_{\mathrm{i}}\right)=\frac{1}{1-R_{i}^{2}},
$$

Where $R_{i}{ }^{2}$ is the squared multiple correlation coefficient between $X_{i}$ and other explanatory variables. The larger the value of VIF, the more troublesome it is. As a rule of thumb, if the VIF of a variable exceeds 10 (this will happen if $R_{i}^{2}$ exceeds 0.95 ), that variable is said to be highly collinear (Gujarati, 1995). On the other hand, as Zhang (2012) pointed out the common distributional assumptions for $\mathrm{u}_{\mathrm{i}}$, are exponential distribution, halfnormal distribution, truncated normal distribution, and gamma distribution. However, since FRONTIER4.1 software was used for the analysis and it performs only half normal and truncated normal distributional assumptions, the best distributional assumption was made through likelihood ratio test (LR) given by Colli et al. (1998) and the value of LR was computed by using the following formula:

$$
\mathrm{LR}=-2\left[\ln \left\{\mathrm{L}\left(\mathrm{H}_{0}\right)\right\}-\ln \left\{\mathrm{L}\left(\mathrm{H}_{1}\right)\right\}\right]
$$

Where $L\left(\mathrm{H}_{0}\right)$ and $L\left(\mathrm{H}_{1}\right)$ denote the values of the likelihood function under the null $\left(\mathrm{H}_{0}\right)$ and alternative $\left(\mathrm{H}_{1}\right)$ hypotheses, respectively. The null hypothesis is rejected when the calculated chi-square is greater than the critical chi-square with degree of freedom (the number of parameters equal to zero at null hypothesis) at $1 \%, 5 \%$, or $10 \%$ level of significance.

The variables that were considered in the production function with their hypothesized sign are presented in Table1.

Similarly, the variables that were considered in the inefficiency model and their hypothesized sign are presented in Table2.

Table 1: Variables used in the production function and their expected sign

\begin{tabular}{cllcc}
\hline No & \multicolumn{1}{c}{ Variables } & \multicolumn{1}{c}{ Description } & Measurement & Expected sign \\
\hline & Output $(\mathrm{Y})$ : Dependent & Quantity of haricot bean output & Quintal & \\
1 & Quantity of local Seed $\left(\mathrm{X}_{1}\right)$ & The amount of local seed applied & $\mathrm{kg}$ & + \\
2 & Quantity of improved Seed $\left(\mathrm{X}_{2}\right)$ & The amount of improved seed applied & $\mathrm{kg}$ & + \\
3 & Di-ammonium fertilizer $\left(\mathrm{X}_{3}\right)$ & The amount of DAP fertilizer applied & $\mathrm{kg}$ & + \\
4 & Cropped land $\left(\mathrm{X}_{4}\right)$ & Total area covered by haricot bean & $\mathrm{kg}$ & + \\
5 & Labor $\left(\mathrm{X}_{5}\right)$ & Total amount of labor used & Adult equivalent & + \\
6 & Number of draught animals $\left(\mathrm{X}_{6}\right)$ & Total number of draught animal the & Number & + \\
\hline
\end{tabular}

\section{RESULTS AND DISCUSSION}

\section{Hypotheses Test}

As indicated in the methodology part, one attractive feature of SPF method is that, it is possible to test various hypotheses. Hence, as presented in Table 3; before discussing about parameter estimates of the models, tests of hypotheses for the parameters of the frontier model, existence of inefficiency and assumptions of the inefficiency distribution were conducted using generalized likelihood ratio statistics (LR) defined by Equation (8).

Therefore, the null hypothesis that half normal model is adequate for the inefficiency term against truncated normal was tested. Hence, from the maximized loglikelihood values under the assumption of half normal and truncated normal distribution for the inefficiency term, the value of LR statistic was calculated which is 1.38 and compared with the critical value of $\chi^{2}$ at $10 \%$ level of significance with one degree of freedom which is 2.71 . Hence, since the calculated value of LR statistic is less than the critical value of $\chi^{2}$ the null hypothesis was accepted indicating that the best distributional assumption for the inefficiency term was half normal.

Similarly, the hypotheses that whether there is inefficiency in the production of haricot bean was tested against the null hypothesis, $\mathrm{H}_{0}: \gamma=\sigma_{u}{ }^{2}=0$ where $\gamma=\sigma_{u}{ }^{2} /$ $\left(\sigma_{u}^{2}+\sigma_{v}{ }^{2}\right)$, such that there is no inefficiency in the production of haricot bean. This hypothesis was tested based on the log likelihood function under OLS estimation and final maximum likelihood estimation. And the generalized likelihood ratio statistics, $L R=6.18$, presented in Table 3 was greater than the critical value of $\chi^{2}$ at $5 \%$ level of significance with two degrees of freedom which is 5.99. Hence, the null hypothesis was rejected at $5 \%$ level of significance showing that the average response function (OLS specification) is not an adequate representation of the data and, the null hypothesis that haricot bean producing farmers in the area were fully efficient was rejected. 
Table 2: Variables used in the inefficiency model and their expected sign

\begin{tabular}{|c|c|c|c|c|}
\hline No & Variables & Description & Measurement & $\begin{array}{l}\text { Expected } \\
\text { sign }\end{array}$ \\
\hline 1 & Inefficiency $\left(\mathrm{U}_{\mathrm{i}}\right)$ & Inefficiency effects & & \\
\hline 2 & $\begin{array}{l}\text { Ownership of draught animals } \\
\left(Z_{1}\right)\end{array}$ & Draught animals ownership & $\begin{array}{l}1=\text { if more than pair } \\
0=\text { otherwise }\end{array}$ & - \\
\hline 3 & Age of the farmer $\left(Z_{2}\right)$ & Years of farmer age & Years & - \\
\hline 4 & $\begin{array}{l}\text { Crop Specific Farm experience } \\
\left(Z_{3}\right)\end{array}$ & $\begin{array}{l}\text { Experience of the farm } \mathrm{HH} \text { in haricot bean } \\
\text { production }\end{array}$ & Years & - \\
\hline 5 & Education $\left(\mathrm{Z}_{4}\right)$ & Years of schooling of farm $\mathrm{HH}$ & Years & - \\
\hline 6 & Farm size $\left(Z_{5}\right)$ & Total operational land holding & ha & + \\
\hline 7 & Extension contact $\left(\mathrm{Z}_{6}\right)$ & Farmers access to extension service & Number & - \\
\hline 8 & Family size $\left(Z_{7}\right)$ & Number of family members & Number & - \\
\hline 9 & Livestock size $\left(Z_{8}\right)$ & Number of TLU & Number & $+/-$ \\
\hline 10 & Off/non-farm activities $\left(Z_{9}\right)$ & $\begin{array}{l}\text { Involvement of farmer in off/non-farm } \\
\text { activities }\end{array}$ & $\begin{array}{l}1=\text { if involved } \\
0=\text { otherwise }\end{array}$ & + \\
\hline 11 & $\begin{array}{l}\text { Access and use of formal Credit } \\
\left(Z_{10}\right)\end{array}$ & $\begin{array}{l}\text { opportunity of farmer access and use of } \\
\text { formal credit }\end{array}$ & $\begin{array}{l}1=\text { if access and use } \\
0=\text { otherwise }\end{array}$ & - \\
\hline $\begin{array}{l}12 \\
13\end{array}$ & $\begin{array}{l}\text { Sex of the household head }\left(Z_{11}\right) \\
\text { Soil fertility }\left(Z_{12}\right)\end{array}$ & Sex of farm $\mathrm{HHH}$ & $1=$ male $; 0=$ female & - \\
\hline 14 & $\begin{array}{l}\text { Proximity to the nearest main } \\
\text { market center }\left(Z_{13}\right)\end{array}$ & $\begin{array}{l}\text { Distance of farmer residence from nearest } \\
\text { the main market }\end{array}$ & $\mathrm{km}$ & + \\
\hline 15 & $\begin{array}{l}\text { Market availability and price } \\
\text { condition of the output }\left(Z_{14}\right) \text { : }\end{array}$ & $\begin{array}{l}\text { Perception of farmer about availability of } \\
\text { market and price condition of haricot bean }\end{array}$ & $\begin{array}{l}1=\text { if perceived available } \\
\text { and price } \\
\text { is attractive } \\
0=\text { otherwise } \\
1=\text { if farmer use more }\end{array}$ & - \\
\hline 16 & Use of hired labor $\left(Z_{15}\right)$ & Farmers use of hired labor & $\begin{array}{l}\text { than family labor } \\
0=\text { otherwise }\end{array}$ & + \\
\hline 17 & Cooperative membership $\left(Z_{16}\right)$ & $\begin{array}{l}\text { Membership of farmer in farmers } \\
\text { cooperatives }\end{array}$ & $\begin{array}{l}1=\text { member } \\
0=\text { otherwise }\end{array}$ & - \\
\hline
\end{tabular}

Table 3: Generalized likelihood-ratio test of hypotheses for parameters of SFP

\begin{tabular}{|c|c|c|c|c|}
\hline Null hypotheses & Description of the null hypotheses & LR statistic & Critical value & Decision \\
\hline $\mathrm{H}_{0}:{ }^{\mu}=0$ & Half normal model is adequate & 1.38 & 2.71 & Accept $\mathrm{H}_{0}$ \\
\hline $\mathrm{H}_{0}: \mathrm{\gamma}=\sigma_{\mathrm{u}}{ }^{2}=0$ & There is no inefficiency effects in the model & 6.18 & 5.99 & Reject $\mathrm{H}_{0}$ \\
\hline $\mathrm{H}_{0}: \mathrm{U}_{\mathrm{i}}=\delta_{0}=\delta_{1} \ldots=\delta_{16}=0$ & $\begin{array}{l}\text { The coefficients of the explanatory variables } \\
\text { associated with technical inefficiency effects model } \\
\text { are all zero }\end{array}$ & 78.34 & 34.8 & Reject $\mathrm{H}_{0}$ \\
\hline
\end{tabular}

Moreover, the null hypothesis that the explanatory variables associated with technical inefficiency effects model are all zero, Ho: $U_{i}=\delta_{0}=\delta_{1}=\delta_{2} \ldots=\delta_{16}=0$ were tested. Likewise, the LR statistic was calculated using the value of log likelihood function under the OLS estimation and the full frontier model (a model with explanatory variables that are presumed to determine inefficiency of each farmer). Hence, the calculated value of $L R=78.34$ was greater than the critical value of $\chi^{2}$ at $1 \%$ level of significance with 18 degrees of freedom(number of restriction) which is 34.8 , thus the null hypothesis that the coefficients of the explanatory variables in the inefficiency effects model are simultaneously equal to zero was rejected at $1 \%$ level of significance. Therefore, the explanatory variables associated with inefficiency effects model are simultaneously different from zero.

\section{Stochastic Cobb-Douglas Production Function Model Results}

The stochastic Cobb-Douglas production function maximum likelihood estimates of the parameters defined by equation 6 are presented in Table 4 .

The model result shows that the variance of the technical inefficiency parameter $\gamma$ was 0.869 and is significantly different from zero as presented in the test of hypotheses. This implies that $86.9 \%$ of the variations in haricot bean output were due to technical inefficiency whereas the remaining $14.1 \%$ were due to random error beyond the control of farmers. In addition to this, the following elasticities were generated from the stochastic production frontier estimation: local seeds (0.472), improved seeds (0.483), DAP fertilizer $(0.011)$, size of allocated land $(0.125)$, labor $(-0.128)$, and number of draught animals (0.006). Hence, the resulting returns to scale parameter obtained by summing these input elasticities is 0.969 . This indicates that haricot bean production in the study area exhibits constant returns to scale. The largest elasticity of improved seed, followed closely by local seed suggests that any interventions on improvement in the use of improved and local seed would create significant achievements in haricot bean productivity improvement.

In addition to this, the results showed a positive coefficient for seeds (improved and/or local) as was hypothesized. Both improved and local seeds had a strong significant effect on haricot bean productivity at $1 \%$ level of significance. According to the finding, a $1 \%$ increase in the quantity of local and/or improved seed usage significantly increases haricot bean yield by 0.472 and $0.483 \%$ respectively. The finding is consistent with the findings of Idiong (2007), Wakili (2012), and Endrias et al. (2013). 
Table 4: MLEs for parameters of the Cobb-Douglas stochastic production function

\begin{tabular}{|c|c|c|c|c|}
\hline \multicolumn{5}{|c|}{ Production factors } \\
\hline Variable & Parameters & Coefficient & Std. error & t-ratio \\
\hline Constant & $\beta_{0}$ & $16.892^{*}$ & 1.552 & 10.882 \\
\hline Local seed & $\beta_{1}$ & $0.472^{*}$ & 0.083 & 5.654 \\
\hline Improved seed & $\beta_{2}$ & $0.483^{*}$ & 0.083 & 5.802 \\
\hline DAP fertilizer & $\beta_{3}$ & $0.011^{* *}$ & 0.006 & 1.793 \\
\hline Allocated land & $\beta_{4}$ & $0.125^{*}$ & 0.047 & 2.677 \\
\hline Labor (both hired and family) & $\beta_{5}$ & $-0.128^{* *}$ & 0.066 & -1.943 \\
\hline Number of draught animals & $\beta_{6}$ & $0.006^{*}$ & 0.002 & 2.829 \\
\hline \multicolumn{5}{|c|}{ Diagnostic statistics } \\
\hline Total variance & $\sigma^{2}$ & 0.123 & 0.023 & 5.474 \\
\hline Variance ratio & $\gamma$ & 0.869 & 0.074 & 11.764 \\
\hline Log likelihood & - & - & - & 10.69 \\
\hline Number of observations & & & & 178 \\
\hline
\end{tabular}

Similarly, the estimated coefficient of Di-ammonium phosphate (DAP) fertilizer was positive as expected and significant at $5 \%$ level showing that a $1 \%$ increase in the use of DAP fertilizer up to the recommended level improves the productivity of land which leads to improvement in the productivity of haricot bean among farmers by $0.011 \%$. This is in line with the findings of Owuor and Ouma (2009) and Tchale (2009).

Moreover, the findings also showed a positive coefficient for size of cropped land as was hypothesized. It has a strongly significant influence on haricot bean productivity at $1 \%$ level of significance telling that, an increase in size of cropped land by $1 \%$ significantly increases haricot bean productivity by $0.125 \%$ and the result is in line with Umoh (2006) and Goni et al. (2007).

Furthermore, the coefficient of labor measured in terms of adult equivalent was negative and significant at $5 \%$ level of significance. The negative elasticity of labor indicates that farmers are over-utilizing it, implying that a $1 \%$ reduction in the amount of labor used improves the yield by $0.128 \%$; the result is in agreement with the result of Tshilambilu (2011) and Goldman (2013). Finally, the number of draught animals a farmer owned has a positive and significant influence on the productivity of the crop implying that keeping all other factors constant, a $1 \%$ increase in number of draught animals increases haricot bean yield by $0.006 \%$.

\section{Technical Efficiency Scores}

Given the functional form used, estimation procedure implemented, distributional assumption of inefficiency component $\left(u_{i}\right)$, individual efficiency score were estimated and the mean technical efficiency of haricot bean producing farmers in the area was $78.25 \%$ (Table 5 ). This value indicates that farmers in the study area are not technically efficient in producing haricot bean. On average, they can increase the current level of output by $21.75 \%$ without increasing the existing level of local seed, improved seed, DAP fertilizer and number of draught animals. In addition to this, there is a considerable difference in technical efficiency among farmers that ranges from a minimum of $44.91 \%$ to a maximum of $95.47 \%$.

Table 5: Estimated technical efficiency scores

\begin{tabular}{lc}
\hline Items & TE scores (\%) \\
\hline Mean & 78.25 \\
Minimum & 44.91 \\
Maximum & 95.47 \\
Standard deviation & 11.95 \\
\hline
\end{tabular}

\section{Determinants of Technical Efficiency}

The main interest behind measuring technical efficiency level is to know the factors that determine the technical efficiency level of individual farmers. As presented in Table 6 , the technical inefficiency effect estimates represented by $\delta_{i}$ revealed that, out of sixteen hypothesized variables only nine of them were significant. These are farmer's ownership of draught animals, Age, total farm size, extension contact, livestock size, involvement in off/nonfarm activities, soil fertility, availability of market and price condition of the output and proximity to the nearest market center. And except livestock size, the sign of all these significant variables were as hypothesized. However, haricot bean production experience, level of education achieved, family size, access and use of formal credit, sex, use of hired labor and cooperative membership were not significant. But except access and use of formal credit, the sign of the coefficient associated with these variables were as expected.

The sign of the estimated coefficient in the model have important implication on the technical efficiency of haricot bean production. Here, the negative sign of a variable in the technical inefficiency model shows that improvement in that variable has positive contribution towards reduction in the technical inefficiency of farmers or the variable improves the technical efficiency of farmers. On the other hand, the positive sign of a variable in the technical inefficiency model shows that increment in that variable aggravates the technical inefficiency of farmers or the variable makes farmers technically less efficient

The age of respondents has a significant negative effect on inefficiency of haricot bean producing farmers at $10 \%$ level of significance as was hypothesized. This indicates that as the age of farmers increases their inefficiency reduces which leads to improvement in the level of technical efficiency this may be due to the reason that farmers may be come more skillful as they grow older and the result is in line with the results of Kibara (2005), Illukpitiya (2005) and Abdullah (2006). However, haricot bean production experience, education, family size, and sex were not significant. Similarly, the coefficient associated ownership of draught animals of farm house hold was negative and significant at $10 \%$ level of significance telling that having pair or more draught animals reduces the inefficiency of farmers. This is in agreement with (IFPRI, 2011b) which states having a pair or more oxen makes farmers to accomplish their farm operations on time and adopt improved technologies and practices which minimizes their technical inefficiency. 
Table 6: Maximum likelihood estimates for parameters of the inefficiency model

\begin{tabular}{lcccc}
\hline \multicolumn{1}{c}{ Inefficiency variables } & Parameters & Coefficients & Std. error & t-ratio \\
\hline Constant & $\delta_{0}$ & $0.504^{* *}$ & 0.195 & 2.591 \\
Draught animals ownership & $\delta_{1}$ & $-0.099^{* * *}$ & 0.058 & -1.709 \\
Age of farmers & $\delta_{2}$ & $-0.004^{* * *}$ & 0.002 & -1.732 \\
Haricot bean production experience & $\delta_{3}$ & -0.001 & 0.002 & -0.478 \\
Level of education & $\delta_{4}$ & -0.001 & 0.006 & -0.193 \\
Total farm size & $\delta_{5}$ & $0.088^{* *}$ & 0.038 & 2.300 \\
Extension contact & $\delta_{6}$ & $-0.025^{* * *}$ & 0.014 & -1.813 \\
Family size & $\delta_{7}$ & -0.000 & 0.007 & -0.008 \\
Livestock size & $\delta_{8}$ & $0.020^{* *}$ & 0.009 & 2.143 \\
Involvement in off/nonfarm activities & $\delta_{9}$ & $0.115^{* *}$ & 0.054 & 2.128 \\
Access and use of formal credit & $\delta_{10}$ & 0.048 & 0.076 & 0.632 \\
Sex & $\delta_{11}$ & -0.036 & 0.077 & -0.472 \\
Soil fertility & $\delta_{12}$ & $-0.101^{* *}$ & 0.043 & -2.347 \\
Proximity to the nearest market center & $\delta_{13}$ & $0.021^{* * *}$ & 0.011 & 1.950 \\
Availability of market and price condition & $\delta_{14}$ & $-0.124^{* *}$ & 0.057 & -2.180 \\
Use of hired labor & $\delta_{15}$ & 0.028 & 0.053 & 0.523 \\
Cooperative membership & ${ }^{* * *}$ Significant at $10 \%,{ }^{* *}$ Significant at $5 \%,{ }^{*}$ significant at $1 \%$. & 0.073 & -0.718 \\
\hline
\end{tabular}

Farm size was found to have a positive effect on inefficiency of farmers as hypothesized and significant at $5 \%$ level of significance. According to the result, those who have large total farm size are less efficient than their counter part. This may be due to the fact that farmers with larger farms are unable perform different farm operations on time and difficult to use agricultural inputs as per recommended and hence increasing technical inefficiency of farmers. The finding is in agreement with Edeh and Awoke (2009), Tchale (2009) and Niringiye et al. (2010).

Number of livestock the respondents have in terms of tropical livestock unit was hypothesized to have negative influence in the inefficiency model; however the finding shows that, the coefficient is positive and significant at $10 \%$ level of significant indicating that farmer with higher livestock holding are less efficient than those who have less livestock size. This may be due to the reason that those farmers who held higher livestock may tend to give attention to livestock production and hence may not be efficient in the production and the finding is in line with. In addition to this, fertility status of farmers' crop land has negative and significant influence on the inefficiency of farmers at $5 \%$ level of significance implying that farmers having fertile land were more efficient than those who have less fertile land. This may be associated with those fertile lands require less commercial fertilizer application which leads to reduction in cost and time and again leads to reduction in the inefficiency of farmers. This is consistent with the finding of Shumet (2011).

Furthermore, the finding of the study also prevails that farmers' involvement in off/no-farm activities influences the inefficiency of haricot bean producing farmers positively at $5 \%$ significance level. This implies that being involved in off/non-farm activities increase the inefficiency of farmers which leads to decline in the technical efficiency of farmers.

Extension services also showed a negative and significant influence on the inefficiency of haricot bean producing farmers at $5 \%$ level of significance. This indicates that having more number of extension contacts improves the technical inefficiency of farmers which in turn improves the technical efficiency of farmers. This suggests that access to extension services enabled farmers to obtain information on new technologies and practices on time. The finding is in line with the findings of Abedullah et al. (2006) and Seidu (2008) who observed that farmers who get adequate extension contacts are able to access modern agricultural technology for input mobilization, input use and disease control, which enable them to reduce technical inefficiency.

Moreover, perception of respondents on availability of market for haricot bean output and its price condition influences the inefficiency of haricot bean producing farmers negatively and significantly at $10 \%$ level of significance. This shows that those farmers who perceived that the market and price condition of the output is attractive were more technically efficient than their counter part and the finding is in line with Messay et al. (2013).

Finally, the finding of the study shows that the coefficient associated with the proximity to the nearest market was positive and significant at 5\% level of significant meaning that it aggravates the inefficiency of target farmers significantly which leads to reduction in the technical efficiency of farmers. According to the finding, a farmer whose residence is far from the main market is less efficient than those whose residence is near to the main market. The result is attributed to the fact that a farm located far from the main market incurs more costs to transport farm inputs and out puts from and to the market which in turn consumes time compared to the one closer to the market and the finding is consistent with the results. However, the contribution of access and use of formal credit and cooperative membership in reducing the inefficiency of farmers were not significant.

\section{CONCLUSIONS}

The study analyses the technical efficiency of farmers in production of haricot bean in East Badawacho Woreda. Stochastic frontier model with inefficiency effects was used for analyzing cross sectional data obtained from 178 sample farmers in 2014 production year. Individual technical efficiency score of farmers was estimated based on the data. On the other hand various farm and farmer 
Hassen Nurhussen et alo,

specific socio-economic and institutional variables that are expected to determine the technical inefficiency of farmers were estimated simultaneously with the stochastic frontier model (one stage estimation procedure).

The estimated stochastic frontier Cobb-Douglas production function indicates that the quantity of local seed, improved seed, amount of DAP fertilizers, land allocated for haricot bean and number of draught animals were positive and significant determinants of production level. The positive coefficient of these parameters indicates that increased use of these inputs will increase the production level to greater extent. However the amount of labor used was negative and significantly influences the level of haricot bean output. This indicates that labor is used in excess in the study area.

The test result reveals that the traditional average response function is not an adequate representation of production frontier. The inefficiency was significant source of variation in haricot bean output among haricot bean producing farmers. This implies that there is a room for improvement in output through improvement in the inefficiency of farmers.

Identifying factors that determine the technical inefficiency level of farmers in haricot bean production helps to improve the technical efficiency of farmers. Hence, the generalized likelihood-ratio test proved that variables considered in the inefficiency effects model simultaneously explained the existing technical efficiency differences among farmers. The estimated SPF model together with the inefficiency parameters show that draught animals ownership, age of farmers, soil fertility and availability of market and price condition of the output have negative and significant influence on the inefficiency of farmers implying that these variables reduce the inefficiency of farmers. On the other hand, the significant and positive sign of total farm size, livestock size, involvement in off/non-farm activities and Proximity to the nearest market center shows that these variables will affect the technical efficiency of farmers negatively implying that an increase in these variables will aggravate the inefficiency of farmers which in turn reduces the technical efficiency of farmers.

Finally, the existence of inefficiency level in haricot bean production together with determinants of inefficiency variables has important policy implications. First the positive elasticity of local seed, improved seed, fertilizer, area coverage of haricot bean and number of draught animals indicates the need to make efforts in improving the dissemination and introduction of these inputs. However, the negative elasticity of labor used tells that the input is used in excess in the study area. On the other hand, the existence of inefficiency among haricot bean producing farmers indicates the possibility of improving the existing level of output with the existing level of technology. Thus, integrated development efforts that will improve the existing level of input use and policy measures that will decrease the existing level of inefficiency will have paramount importance in improving the living standard of farmers through improving haricot bean productivity.

Therefore, the attention of policy makers to improve the livelihood of farmers and mitigate the existing level of food deficiency through improvement in haricot bean
Sci. Technol. Arts Res. J., Jan-March 2015, 4(1): 234-241

production should not stick only to the introduction and dissemination of inputs like seed (both local and improved), DAP fertilizer and drought animal but also should give due attention towards improving the existing level of efficiency among haricot bean producing farmers. Because, improvement in haricot bean output through improvement in the existing technology is expensive, require relatively longer time to achieve and farmers have financial problems, it is better to work towards improvement in the efficiency of farmers so that farmers will use the existing technology efficiently.

\section{Conflict of Interest}

Conflict of interest none declared.

\section{REFERENCES}

Abdullah, B.K. and Ahmad, B. (2006). Technical Efficiency and its Determinants in Potato Production, Evidence from Punjab, Pakistan. The Lahore Journal of Economics 11: (2):1-22

Battese, G. E. and Coelli, T. J. (1995). A Model for Technical Inefficiency Effects in a Stochastic Frontier Production Function for Panel Data. Empirical Economics 20: 325332.

Battese, G.E. and Corra, G.S. (1977). Estimation of a Production Frontier Model: With Application to the Pastoral Zone of Eastern Australia. Australian Journal of Agricultural Economics 21(3): 169-179.

Chirwa, E.W. (2007). Sources of Technical Efficiency among Smallholder Maize Farmers in Southern Malawi. AERC Research Paper 172 African Economic Research Consortiums, Nairobi November 2007: 12-14.

Constantin, P.D., Martin, D.L. and Y Rivera, E.B. (2009). Cobb-Douglas, Translog Stochastic Production Function and Data Envelopment Analysis in Total Factor Productivity in Brazilian Agribusiness. The Flagship Research Journal of International Conference of the Production and Operations Management Society 2(2): 2034.

Coelli, T.J., Rao, D.S.P. and., Battese, G.E. (1998). An Introduction to Efficiency and Productivity Analysis. Kluwer Academic Publishers.

CSA (Central Statistics Agency), (2009). Annual Agricultural Sample Survey (database)

CSA, (2010). Agricultural Sample Survey Report on Area and Production of Crops (Private Peasant Holdings, Meher Season). Statistical Bulletin, Addis Ababa.

CSA, (2012). Crop Production Forecast Sample Survey. Statistical Bulletin, Addis Ababa.

Endrias Geta., Ayalneh Bogale., Belay Kassa and Eyasu Elias, (2013). Productivity and Efficiency Analysis of Smallholder Maize Producers in Southern Ethiopia. The Journal of Human Ecology 41(1): 67-75.

Edeh, H.O. and Awoke, M.U. (2009). Technical efficiency analysis of improved cassava farmers in Abakaliki Local Government Area of Ebonyi state, Nigeria: A stochastic frontier approach. Agricultural Journal 4(4):171-174.

EARO (Ethiopian Agricultural Research Organization), (2004). Directory of Released Crop Varieties \& Their Recommended Cultural Practices Addis Ababa.

EEPA (Ethiopian Export Promotion Agency), (2004). Ethiopian Pulses Profile. Product Development \& Market Research Directorate Ethiopia. 
Hassen Nurhussen et alo,

Goldman, D. (2013). Technical efficiency of rice production in India. A study using stochastic frontier analysis to estimate Technical efficiency and its determinants. Master of Arts in Law and Diplomacy. Pp: 14-15

Goni, M., Mohammed, S. and. Baba, B.A. (2007). Analysis of Resource-Use Efficiency in Rice Production in the Lake Chad Area of Borno State, Nigeria. Journal of Sustainable Development in Agriculture and Environment 3: 31-37.

Gujarati, D.N., (1995). Basic econometrics. 3rd edition, McGraw Hill, Inc., New York.

Hyuha, T.S., Bashaasha, B. Nkonya, E. and Kraybill, D. (2007). Analysis of Profit Inefficiency in Rice Production in Eastern and Northern Uganda. African Crop Science Journal 15(4): 243-253.

Idiong, I.C. (2007). Estimation of Farm Level Technical Efficiency in Small scale Swamp Rice Production in Cross River State of Nigeria: A Stochastic Frontier Approach. World Journal of Agricultural Sciences 3(5):656-657.

Illukpitiya, P., (2005). Technical Efficiency in Agriculture and Dependency on Forest Resources: An economic analysis of rural households and the conservation of natural forests in Sri Lanka.

Katungi, E., Farrow, A., Mutuoki, T., Gebeyehu, S., Karanja, D., Alamayehu, F., Sperling, L., Beebe, S., Rubyogo, J.C., and Buruchara, R. (2010). Improving Common Bean Productivity: An Analysis of Socio-Economic Factors in Ethiopia and Eastern Kenya.

Legese Dadi, (2004). Agricultural Research and Technology Development in Ethiopia. Proceedings of the workshop held to discuss the socio-economic research results of 1998-2002. August 6-8, 2002, Addis Ababa, Ethiopia. EARO, 2004.

Maddala, G.S., (1992). Introduction to Econometrics. Second Edition. New York: Macmillan Publishing Company.

Mesay Yami., Tesafye Solomon., Bedada Begna., Fekadu Fufa., Tolesa Alemu and Dawit Alemu. (2013). Source of Technical Inefficiency of Smallholder Haricot bean Farmers in Selected Waterlogged Areas of Ethiopia: A Translog Production Function Approach. African Journal of Agricultural Research 8(29):3935-3937.
Sci. Technol. Arts Res. J., Jan-March 2015, 4(1): 234-241

Niringiye, A., Luvanda, E., and Shitundu, J. (2010). Firm size, and technical efficiency in East African manufacturing firms. Current Research Journal of Economic Theory 2(2): 69-75.

Owuor, G., and O. A. Shem, 2009. What are the Key Constraints in Technical Efficiency of Smallholder Farmers in Africa? Empirical Evidence from Kenya. 111 EAAE-IAAE Seminar 'Small Farms: decline or persistence' University of Kent, Canterbury, UK, $26^{\text {th }}-27^{\text {th }}$ June 2009.

Seidu, A. (2008). Technical Efficiency of Rice Farmers in Northern Ghana. Tamale, Ghana: AERC Research Paper.

Shumet Asefa. (2011). Analysis of Technical Efficiency of Crop Producing Smallholder Farmers in Tigray, Ethiopia. MPRA Paper No. 40461, Mekelle University.

Tan Bao Hong, (2008). Cobb-Douglas Production Function. docentes.fe.unl.pt/ jamador/Macro/cobb-douglas.pdf

Tchale, H. (2009). The efficiency of smallholder agriculture in Malawi. African Journal of Agricultural and Resource Economics 3(2): 101-121.

Tshilambilu, B. (2011). Technical Efficiency in Maize Production by Small-Scale Farmers in Ga-Mothiba, Limpopo Province, South Africa. A Thesis Submitted to Department of Agricultural Economics and Animal Production, University of Limpopo, South Africa

Umoh, G.S., (2006). Resource use efficiency in urban farming: an application of stochastic frontier production function. International journal of Agriculture and Biolog 8: 34-44.

Wakili, A.M. (2012). Technical Efficiency of Sorghum Production in Hong Local Government Area of Adamawa State, Nigeria. Russian Journal of Agricultural and SocioEconomic Sciences 6(6): 10-15

Yamane, T. (1967). Statistics: An Introductory Analysis. $2^{\text {nd }}$ Ed., New York: Harper and Row.

Zhang, M. (2012). The Comparison of Stochastic Frontier Analysis with Panel Data Models: A Doctoral Thesis Submitted in Partial Fulfillment of the Requirements for the Award of Doctor of Philosophy, School of Business and Economics Loughborough University. 